\title{
THE DISTRIBUTION OF THE THIOSULFATE ION WITH RESPECT TO NORMAL HUMAN SERUM AND RED BLOOD CELLS AND ITS APPLICATION TO "EXTRACELLULAR FLUID" DETERMINATION ${ }^{1}$
}

\author{
BY HENRY J. KOWALSKI AND DAVID D. RUTSTEIN \\ WITH THE TEChNICAL ASSISTANCE OF RUTH I. SCHAUFUS AND JOAN M. SHOULBERG \\ (From the Department of Preventive Medicine, Harvard University Medical School, Boston, Mass.)
}

(Submitted for publication July 7, 1951; accepted February 5, 1952)

Fluid compartment measurements are useful procedures in studying edema, dehydration, and changes in cellular permeability. The general principles involved in such measurements have recently been discussed by Levitt and Gaudino (1). Substances used in the intact animal or in man should fulfill a number of conditions, among them being "uniform distribution throughout the compartment." For "extracellular fluid" estimations, this condition implies equal concentration of the substance throughout all of the intraand extravascular fluid outside of body cells. If the material employed is physically or chemically bound by non-diffusible components of serum, intravascular concentration will exceed extravascular concentration, and uniform distribution will not occur.

Recent work performed in part at this laboratory shows that the thiocyanate ion, heretofore used extensively for estimation of "extracellular fluid" volume, is actually bound to albumin in human serum and therefore is not uniformly distributed throughout the compartment (2). If the concentration of serum albumin is known, its binding effect can be determined by means of a formula (2). However, it is not possible to determine the binding effect of extravascular albumin, since its concentration and distribution cannot be measured.

Gilman, Philips and Koelle suggested the use of another ion, thiosulfate, for estimating "extracellular fluid" volume (3). The present study was undertaken to determine if this anion, like thiocyanate, was bound to any appreciable extent by non-diffusible components of human serum.

1 This study was supported in part by Research Grant H-177 (C) of the National Heart Institute, U. S. Public Health Service.
Thiocyanate is known to penetrate the red blood cell and values for "thiocyanate space" thus may include the water of the red cell mass (2). To determine if thiosulfate also has this property, measurements of the penetration of this anion into the erythrocyte were also made.

\section{METHODS AND PROCEDURES}

The distribution of thiosulfate across cellophane membranes in both the serum and erythrocyte experiments was determined by the same dialysis method previously employed for thiocyanate (2).

\section{Experiments with serum and with saline}

Twenty mls. of normal human serum were pipetted into cellophane sacs. These were placed in tubes containing $40 \mathrm{mls}$. of 0.15 molar sodium chloride in which known amounts of thiosulfate were present. Duplicate tubes were dialyzed for 72 hours at $2^{\circ} \mathrm{C}$. This low temperature minimizes bacterial action on the sera and has no significant effect on binding, since the binding of chloride and of thiocyanate to albumin is the same at $4^{\circ} \mathrm{C}$. as at $25^{\circ} \mathrm{C}$. $(4,5)$.

After dialysis the volume inside and outside was measured and the water content determined by drying to constant weight. The outside thiosulfate concentration was measured in duplicate by the "direct" method of Newman, Gilman, and Philips (6).

Five serum controls were dialyzed separately; 0.0012 mole of thiosulfate was placed inside the sac in three tubes and outside the sac in the remaining two. The outside concentration of "free thiosulfate" in the five tubes must be equal at equilibrium. This condition was satisfied in 72 hours, when outside concentrations were $0.0202,0.0201$, $0.0203,0.0201$, and 0.0199 mole/liter of solution. Thus 72 hours was selected as the terminal point of the distribution experiments on serum.

The range of thiosulfate concentrations in these experiments extends from $2 \mathrm{mgs}$. \% to $320 \mathrm{mgs}$. \% and exceeds the usual range of 10 to $60 \mathrm{mgs}$. \% employed in clearance studies. This latter range would be a suitable one for measurement of "thiosulfate space." Duplicate saline 
controls at the same thiosulfate concentration were run to measure any binding of the anion by the cellophane sacs.

From a knowledge of the total water content, the total number of moles of thiosulfate in the system, and outside thiosulfate concentration, the number of moles of thiosulfate bound to non-diffusible components of serum was determined as in the studies with thiocyanate (2).

Let $\Delta \mathbf{n}$ be defined in terms of known and experimentally determined values as the difference between the amount of the anion known to be present and the amount which can be recovered in the total water in the system: or

$$
\Delta \mathrm{n}=\left[\mathrm{n}_{0}-\mathrm{n}_{\mathrm{c}}\right]-\left[\mathrm{g}+\mathrm{g}^{\prime}\right]\left(\mathrm{S}_{\mathbf{2}} \mathrm{O}_{\mathbf{z}}^{-}\right)^{\prime},
$$

where

$n_{0}=$ total number of moles of thiosulfate in the system; $n_{c}=$ number of moles of thiosulfate bound to cellophane as determined from saline controls;

$\mathbf{g}+\mathbf{g}^{\prime}=$ total water of the system in kilograms, with $\mathbf{g}$ referring to the water inside, and $g^{\prime}$ to the water outside the sac;

$\left(\mathrm{S}_{2} \mathrm{O}_{3}\right)$ = concentration in moles per $\mathrm{Kg}$. of water of unbound thiosulfate ion inside the membrane, and

$\left(\mathrm{S}_{2} \mathrm{O}_{\overline{3}}\right)^{\prime}=$ concentration of thiosulfate ion outside the membrane. ${ }^{2}$

Let $n_{b}$ denote the number of moles of bound thiosulfate in serum. Then the relationship of $n_{b}$ to $\Delta n$ can be shown by means of the Donnan equilibrium (2) which for the systems as described becomes:

$$
\begin{aligned}
{\left[\frac{2 \Delta \mathrm{n}}{\mathrm{g}}+2\left(\mathrm{~S}_{2} \mathrm{O}_{\bar{z}}^{\prime}\right)^{\prime}+0.15\right]^{2}\left[\frac{\Delta \mathrm{n}-\mathrm{n}_{\mathrm{b}}}{\mathrm{g}}+\left(\mathrm{S}_{2} \mathrm{O}_{\bar{z}}^{-}\right)^{\prime}\right] } \\
=\left[0.15+2\left(\mathrm{~S}_{2} \mathrm{O}_{\bar{z}}\right)^{\prime}\right]^{2}\left[\left(\mathrm{~S}_{2} \mathrm{O}_{\bar{z}}^{\prime}\right)^{\prime}\right] .
\end{aligned}
$$

The left-hand member of the equation represents the product of the sodium concentration and the thiosulfate concentration inside the sac. The right-hand member is the product of the sodium concentration and the thiosulfate concentration outside the sac.

Dividing equation 2 by $\left[0.15+2\left(\mathrm{~S}_{2} \mathrm{O}_{3}^{-}\right)^{\prime}\right]$ one obtains

$$
\left[\frac{\frac{2 \Delta n}{g}}{0.15+2\left(\mathrm{~S}_{2} \mathrm{O}_{\overline{3}}\right)^{\prime}}+1\right]^{2}\left[\frac{\Delta \mathrm{n}-\mathrm{n}_{\mathrm{b}}}{\mathrm{g}}+\left(\mathrm{S}_{2} \mathrm{O}_{\overline{3}}^{-}\right)^{\prime}\right]=\left[\left(\mathrm{S}_{2} \mathrm{O}_{\overline{3}}^{\prime}\right)^{\prime}\right] \text {. }
$$

Inspection of the first factor on the left indicates that when $\Delta n$ approaches zero the value of the first factor on the left approaches 1 , and at zero, equation 3 reduces to:

$$
\Delta \mathbf{n}=\mathbf{n}_{\mathrm{b}}=\mathbf{0}
$$

If there is no binding, the experimentally determined values of $\Delta \mathbf{n}$ would be expected to vary in a chance distribution about zero. If there is binding, this relationship, $\Delta \mathbf{n}=n_{b}$, would not hold and $n_{b}$ can be calculated from equation 3 .

It has been assumed in this derivation that the sodium ion is not bound appreciably to serum proteins $(4,5)$.

2 Primed quantities refer to outside protein-free solution and unprimed quantities to the solution within the sac.

\section{Permeability experiments with red blood cells}

To determine if thiosulfate penetrates the erythrocyte, dialysis experiments similar to the studies on serum were performed. Fresh defibrinated blood from a healthy donor was centrifuged and washed four times with $0.15 \mathrm{M}$ sodium chloride. The hematocrit after the final washing and centrifugation was $98 \%$.

A preliminary experiment to assure measurement at equilibrium was performed as in the case of the serum experiments. Ten mls. of washed erythrocytes were pipetted into cellophane sacs in a series of tubes numbered 1 to 8. Identical amounts of thiosulfate, $2.43 \times 10^{-4}$ moles, in $0.15 \mathrm{M}$ sodium chloride were pipetted directly into the tube outside the sacs in tubes 1 and 2 , and inside the sacs in tubes 3 and 4 . The final volume of the entire tube was made up to $60 \mathrm{mls}$. with $0.15 \mathrm{M}$ sodium chloride, $20 \mathrm{mls}$. inside and $40 \mathrm{mls}$. outside the sac. Tubes $5,6,7$, and 8 were prepared exactly as the first four but the amount of thiosulfate used was $1.21 \times 10^{-4}$ moles. This quantity was placed inside the sac in tubes 5 and 6 , and outside in tubes 7 and 8. After dialyzing at $2^{\circ} \mathrm{C}$. the contents were measured, the outside thiosulfate concentration determined, and well-mixed inside and outside aliquots were dried to constant weight to determine the water content. At 48 hours the thiosulfate concentration $\left(\mathrm{S}_{2} \mathrm{O}_{\overline{3}}\right)^{\prime}$ in tubes $1,2,3$, and 4 was $0.00407,0.00407,0.00408$, and 0.00409 mole per $\mathrm{Kg}$. of water. The concentration in tubes 5, 6, 7 , and 8 was $0.00181,0.00183,0.00155$, and 0.00186 mole per $\mathrm{Kg}$. of water, respectively. Thus 48 hours was selected as the terminal point of the erythrocyte penetration experiments.

The penetration of thiosulfate into the erythrocyte can be determined from a knowledge of the total thiosulfate in the system, $n_{0}$, from the total water content including the red blood cell water $\left[g+g^{\prime}\right]$, and from the thiosulfate concentration outside the $\operatorname{sac}\left(\mathrm{S}_{2} \mathrm{O}_{3}^{-}\right)^{\prime}$, by comparing the quantity $\left(n_{0}-n_{c}\right.$ ) with the quantity represented by $\left[\mathrm{g}+\mathrm{g}^{\prime}\right]\left(\mathrm{S}_{2} \mathrm{O}_{\overline{3}}^{-}\right)^{\prime}$ (equation 1 ).

In the experiments with red blood cells, no attempt was made to correct for the Donnan equilibrium across the red blood cell membrane.

\section{RESULTS}

The results of the experiments are shown in Table I with the saline controls (Part A), the serum dialysis experiments (Part $B$ ), and the erythrocyte penetration studies (Part C). The columns are numbered 1 to 8 . Column 1 is the tube number. Column 2 is the number of moles of thiosulfate known to be present in each system, $\mathrm{n}_{0}$. Column 3 is the thiosulfate concentration $\left(\mathrm{S}_{2} \mathrm{O}_{\overline{3}}^{\prime}\right)^{\prime}$, of the outside solution. Column 4 is the concentration inside the cellophane sac $\left(\mathrm{S}_{2} \mathrm{O}_{\overline{3}}\right)$, as determined experimentally. Column 5 represents the total water of the system $\left[g+g^{\prime}\right]$ and Column 6 the water inside the sac, $g$. The 
TABLE I

Distribution experiments with thiosulfate

\begin{tabular}{|c|c|c|c|c|c|c|c|c|}
\hline & 1 & 2 & 3 & 4 & 5 & 6 & 7 & 8 \\
\hline & \multirow[t]{2}{*}{$\begin{array}{l}\text { Tube } \\
\text { no. }\end{array}$} & $\begin{array}{c}\text { Thiosulfate } \\
\text { in system } \\
\text { (moles) }\end{array}$ & 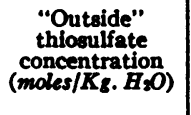 & $\begin{array}{c}\text { "Inside" } \\
\text { thiosulfate } \\
\text { concentration } \\
\text { (moles/Kg. } H_{2} O \text { ) }\end{array}$ & $\begin{array}{c}\text { Total } \mathrm{H}_{0} \mathrm{O} \\
\text { of system } \\
\mathrm{K}_{\boldsymbol{B}} .\end{array}$ & $\begin{array}{c}\mathrm{H}_{\mathbf{5}} \mathrm{O} \text { inside } \\
\text { gac } \\
\mathbf{K}_{\mathbf{g}} .\end{array}$ & $\begin{array}{c}\text { Free } \\
\text { thiosulfate } \\
\text { (moles) }\end{array}$ & $\underset{\text { (moles) }}{\Delta \mathbf{n}}$ \\
\hline & & $n_{0} \times 10^{4}$ & $\left(\mathrm{~S}_{2} \mathrm{O}_{3}\right)^{\prime} \times 10^{\circ}$ & $\left(\mathrm{S}_{2} \mathrm{O}_{3}\right) \times 10^{3}$ & {$\left[\mathbf{g}+\mathbf{z}^{\prime}\right]$} & $\mathbf{8}$ & 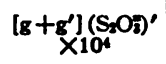 & $\Delta \mathrm{n} \times 10^{\circ}$ \\
\hline \multirow{7}{*}{$\begin{array}{c}\text { A. } \\
\text { Saline } \\
\text { Controls* }\end{array}$} & $\begin{array}{l}1 \\
2\end{array}$ & $\begin{array}{l}11.98 \\
11.98\end{array}$ & $\begin{array}{l}20.1 \\
20.0\end{array}$ & $\begin{array}{l}19.8 \\
19.8\end{array}$ & $\begin{array}{l}0.0606 \\
0.0605\end{array}$ & $\begin{array}{l}0.0195 \\
0.0195\end{array}$ & $\begin{array}{l}12.18 \\
12.10\end{array}$ & $\begin{array}{l}-20.0 \\
-12.0\end{array}$ \\
\hline & $\begin{array}{l}3 \\
4\end{array}$ & $\begin{array}{l}9.072 \\
9.072\end{array}$ & $\begin{array}{l}14.7 \\
15.0\end{array}$ & $\begin{array}{l}14.6 \\
14.7\end{array}$ & $\begin{array}{l}0.0612 \\
0.0601\end{array}$ & $\begin{array}{l}0.0189 \\
0.0190\end{array}$ & $\begin{array}{l}8.90 \\
9.02\end{array}$ & $\begin{array}{l}+17.2 \\
+5.2\end{array}$ \\
\hline & $\begin{array}{l}5 \\
6\end{array}$ & $\begin{array}{l}3.080 \\
3.080\end{array}$ & $\begin{array}{l}5.41 \\
5.34\end{array}$ & $\begin{array}{l}5.20 \\
5.38\end{array}$ & $\begin{array}{l}0.0584 \\
0.0579\end{array}$ & $\begin{array}{l}0.0201 \\
0.0192\end{array}$ & $\begin{array}{l}3.16 \\
3.12\end{array}$ & $\begin{array}{l}-8.0 \\
-4.0\end{array}$ \\
\hline & $\begin{array}{l}7 \\
8\end{array}$ & $\begin{array}{l}3.024 \\
3.024\end{array}$ & $\begin{array}{l}4.98 \\
4.91\end{array}$ & $\begin{array}{l}4.86 \\
4.88\end{array}$ & $\begin{array}{l}0.0594 \\
0.0592\end{array}$ & $\begin{array}{l}0.0194 \\
0.0192\end{array}$ & $\begin{array}{l}2.96 \\
2.91\end{array}$ & $\begin{array}{r}+6.4 \\
+11.4\end{array}$ \\
\hline & $\begin{array}{r}9 \\
10\end{array}$ & $\begin{array}{l}0.770 \\
0.770\end{array}$ & $\begin{array}{l}1.35 \\
1.36\end{array}$ & $\begin{array}{l}1.34 \\
1.38\end{array}$ & $\begin{array}{l}0.0588 \\
0.0578\end{array}$ & $\begin{array}{l}0.0196 \\
0.0193\end{array}$ & $\begin{array}{l}0.790 \\
0.780\end{array}$ & $\begin{array}{l}-2.0 \\
-1.0\end{array}$ \\
\hline & $\begin{array}{l}11 \\
12\end{array}$ & $\begin{array}{l}0.320 \\
0.320\end{array}$ & $\begin{array}{l}0.529 \\
0.535\end{array}$ & $\begin{array}{l}0.530 \\
0.536\end{array}$ & $\begin{array}{l}0.0593 \\
0.0579\end{array}$ & $\begin{array}{l}0.0204 \\
0.0197\end{array}$ & $\begin{array}{l}0.314 \\
0.310\end{array}$ & $\begin{array}{l}+0.6 \\
+1.0\end{array}$ \\
\hline & $\begin{array}{l}13 \\
14\end{array}$ & $\begin{array}{l}0.0816 \\
0.0816\end{array}$ & $\begin{array}{l}0.134 \\
0.134\end{array}$ & $\begin{array}{l}0.146 \\
0.126\end{array}$ & $\begin{array}{l}0.0593 \\
0.0586\end{array}$ & $\begin{array}{l}0.0196 \\
0.0196\end{array}$ & $\begin{array}{l}0.0794 \\
0.0785\end{array}$ & $\begin{array}{l}+0.22 \\
+0.31\end{array}$ \\
\hline \multirow{7}{*}{$\begin{array}{c}\text { B. } \\
\text { Serum } \\
\text { os. } \\
\text { Saline } \\
\text { Systems }\end{array}$} & $\begin{array}{l}15 \\
16\end{array}$ & $\begin{array}{l}11.98 \\
11.98\end{array}$ & $\begin{array}{l}21.8 \\
20.1\end{array}$ & & $\begin{array}{l}0.0592 \\
0.0587\end{array}$ & $\begin{array}{l}0.0255 \\
0.0236\end{array}$ & $\begin{array}{l}12.91 \\
11.80\end{array}$ & $\begin{array}{l}-93.0 \\
+18.0\end{array}$ \\
\hline & $\begin{array}{l}17 \\
18\end{array}$ & $\begin{array}{l}9.072 \\
9.072\end{array}$ & $\begin{array}{l}15.0 \\
14.6\end{array}$ & & $\begin{array}{l}0.0605 \\
0.0602\end{array}$ & $\begin{array}{l}0.0224 \\
0.0235\end{array}$ & $\begin{array}{l}9.08 \\
8.79\end{array}$ & $\begin{array}{r}-0.8 \\
+28.2\end{array}$ \\
\hline & $\begin{array}{l}19 \\
20\end{array}$ & $\begin{array}{l}3.08 \\
3.08\end{array}$ & $\begin{array}{l}5.42 \\
5.35\end{array}$ & & $\begin{array}{l}0.0581 \\
0.0573\end{array}$ & $\begin{array}{l}0.0259 \\
0.0255\end{array}$ & $\begin{array}{l}3.15 \\
3.07\end{array}$ & $\begin{array}{l}-7.0 \\
+1.0\end{array}$ \\
\hline & $\begin{array}{l}21 \\
22\end{array}$ & $\begin{array}{l}3.024 \\
3.024\end{array}$ & $\begin{array}{l}5.18 \\
5.10\end{array}$ & & $\begin{array}{l}0.0578 \\
0.0587\end{array}$ & $\begin{array}{l}0.0251 \\
0.0249\end{array}$ & $\begin{array}{l}2.99 \\
2.99\end{array}$ & $\begin{array}{r}+3.4 \\
+3.4\end{array}$ \\
\hline & $\begin{array}{l}23 \\
24\end{array}$ & $\begin{array}{l}0.770 \\
0.770\end{array}$ & $\begin{array}{l}1.35 \\
1.35\end{array}$ & & $\begin{array}{l}0.0582 \\
0.0575\end{array}$ & $\begin{array}{l}0.0255 \\
0.0249\end{array}$ & $\begin{array}{l}0.786 \\
0.776\end{array}$ & $\begin{array}{l}-1.6 \\
-0.6\end{array}$ \\
\hline & $\begin{array}{l}25 \\
26\end{array}$ & $\begin{array}{l}0.320 \\
0.320\end{array}$ & $\begin{array}{l}0.527 \\
0.560\end{array}$ & & $\begin{array}{l}0.0587 \\
0.0561\end{array}$ & $\begin{array}{l}0.0265 \\
0.0243\end{array}$ & $\begin{array}{l}0.309 \\
0.314\end{array}$ & $\begin{array}{r}+1.1 \\
+0.6\end{array}$ \\
\hline & 27 & 0.0816 & 0.146 & & 0.0579 & 0.0240 & 0.0845 & -0.29 \\
\hline \multirow{4}{*}{$\begin{array}{c}\text { C. } \\
\text { Erythrocyte } \\
\text { vs. } \\
\text { Saline } \\
\text { Systems } \neq\end{array}$} & $\begin{array}{l}31 \\
32\end{array}$ & $\begin{array}{l}2.43 \\
2.43\end{array}$ & $\begin{array}{l}4.07 \\
4.07\end{array}$ & & $\begin{array}{l}0.0573 \\
0.0563\end{array}$ & $\begin{array}{l}0.0180 \\
0.0176\end{array}$ & $\begin{array}{l}2.33 \\
2.29\end{array}$ & $\begin{array}{l}+10 \\
+14\end{array}$ \\
\hline & $\begin{array}{l}33 \\
34\end{array}$ & $\begin{array}{l}2.43 \\
2.43\end{array}$ & $\begin{array}{l}4.07 \\
4.09\end{array}$ & & $\begin{array}{l}0.0544 \\
0.0561\end{array}$ & $\begin{array}{l}0.0174 \\
0.0172\end{array}$ & $\begin{array}{l}2.21 \\
2.29\end{array}$ & $\begin{array}{l}+22 \\
+14\end{array}$ \\
\hline & $\begin{array}{l}35 \\
36\end{array}$ & $\begin{array}{l}1.21 \\
1.21\end{array}$ & $\begin{array}{l}1.81 \\
1.83\end{array}$ & & $\begin{array}{l}0.0572 \\
0.0564\end{array}$ & $\begin{array}{l}0.0180 \\
0.0182\end{array}$ & $\begin{array}{l}1.03 \\
1.03\end{array}$ & $\begin{array}{l}+18 \\
+18\end{array}$ \\
\hline & $\begin{array}{l}37 \\
38\end{array}$ & $\begin{array}{l}1.21 \\
1.21\end{array}$ & $\begin{array}{l}1.55 \\
1.86\end{array}$ & & $\begin{array}{l}0.0563 \\
0.0567\end{array}$ & $\begin{array}{l}0.0176 \\
0.0183\end{array}$ & $\begin{array}{l}0.87 \\
1.05\end{array}$ & $\begin{array}{l}+34 \\
+16\end{array}$ \\
\hline
\end{tabular}

* For saline controls mean $\Delta \mathrm{n} \pm$ S.E. $=(-.33 \pm 1.13) \times 10^{-6}$.

$\dagger$ For serum systems mean $\Delta \mathrm{n} \pm$ S.E. $=(-3.94 \pm 9.58) \times 10^{-6}$.

$\ddagger$ For erythrocyte systems mean $\Delta n \pm$ S.E. $=(18.2 \pm 2.6) \times 10^{-6}$. 
seventh column represents the free thiosulfate of the entire system in moles $\left[\mathrm{g}+\mathrm{g}^{\prime}\right]\left(\mathrm{S}_{2} \mathrm{O}_{\overline{3}}^{\prime}\right)^{\prime}$. The eighth column represents the values obtained for $\Delta \mathrm{n}$. In saline controls, $\Delta \mathrm{n}$ represents thiosulfate bound to cellophane, $\mathrm{n}_{\mathrm{c}}$.

\section{A. Experiments with saline}

If there were no appreciable binding to cellophane, the values of $\Delta \mathrm{n}$ in Column 8 , Part $A$, would be expected to fall in a chance distribution about zero, the deviations from zero representing experimental variability. Inspection suggests that the observed values do in fact represent chance deviations from zero. To evaluate this hypothesis, a " $t$ " test was used with the standard error of the mean $\Delta \mathrm{n}$ computed from the variance within duplicate experiments. The mean $\Delta \mathrm{n}$ for saline controls was $-0.33 \times 10^{-6}$. A difference from zero of this amount or greater could occur by chance with a probability of about 0.8 . The observed values are thus consistent with the belief that there is no appreciable binding to cellophane.

\section{B. Experiments with serum}

Since no binding to cellophane could be demonstrated for the saline controls, $n_{c}$ becomes zero and for serum, Column 8 represents $\Delta \mathrm{n}=\mathrm{n}_{0}-\left[\mathrm{g}+\mathrm{g}^{\prime}\right]\left(\mathrm{S}_{2} \mathrm{O}_{\overline{3}}\right)^{\prime}$. As indicated above in equation 4 , when $\mathrm{n}_{\mathrm{b}}=0, \Delta \mathrm{n}=\mathrm{n}_{\mathrm{b}}$. Inspection of Column 8 for serum suggests that the values of $\Delta \mathrm{n}$ represent chance deviations from zero, with a mean deviation of $-3.94 \times 10^{-6}$. The probability of observing a chance difference of this size or greater is about 0.7. Thus there is no appreciable binding to any non-diffusible component of serum and hence not to albumin.

\section{Experiments with red blood cells}

Since $\mathrm{n}_{\mathrm{c}}=0$, the equation again becomes $\Delta \mathrm{n}=\mathrm{n}_{0}-\left[\mathrm{g}+\mathrm{g}^{\prime}\right]\left(\mathrm{S}_{2} \mathrm{O}_{\overline{3}}^{-}\right)^{\prime}$. Table I, Part C, reveals that in all systems $\Delta n>0$. The observed values of $\Delta n$ thus indicate that in all tubes some thiosulfate is not accounted for.

\section{DISCUSSION}

In the range studied, which extended from about $2 \mathrm{mgs}$. \% to $320 \mathrm{mgs}$. \%, no measurable binding of thiosulfate to non-diffusible compo- nents of human serum was noted. Thus, with respect to serum, thiosulfate satisfies the general requirement of "uniform distribution throughout the compartment."

At concentrations of about 30 and 60 mgs. $\%$ under the experimental conditions $\left(2^{\circ} \mathrm{C}\right.$. over a 48 hr. period) a small amount of thiosulfate in each system was unaccounted for. The results of the experiments in Part $\mathrm{C}$ appear to indicate that the concentration of thiosulfate in the red cell is higher than the concentration outside of the red cell, i.e., that there may be binding of thiosulfate to the red cell. There is a discrepancy in that $\Delta \mathrm{n}$ is greater in tubes 35 through 38 inclusive than it is in tubes 31 through 34 inclusive (with the exception of tube 33), although the total thiosulfate in tubes $31-34$ is twice that in tubes 35-38. Such a result is contrary to the law of mass action. Finally the possibility remains that the red cells may have destroyed some thiosulfate by their metabolism. The anomalous results just referred to might then be explained if the metabolism of the red cell were depressed in the presence of the higher thiosulfate concentration.

The experiments reported here give no information regarding the rate of penetration of thiosulfate into the red blood cell. If in vivo penetration is slow, the effect is the same as that of another route of excretion and hence can easily be corrected for by extrapolation of logarithmic values for serum concentration to zero time and, in this instance, the red blood cell water would not enter into the determined value for thiosulfate space. If in vivo red blood cell penetration is as rapid as diffusion into extracellular fluid space, the red blood cell water becomes a functional part of the "extracellular fluid" volume and would be included in the value for thiosulfate space. The total red blood cell water amounts to a volume of about 1,400 to $1,500 \mathrm{mls}$. when calculated by multiplying the total erythrocyte volume by 0.65 , the fraction of water in the erythrocyte $(7,8)$. For a $70 \mathrm{Kg}$. man this quantity is approximately $8.5 \%$ of the thiocyanate space (uncorrected for binding by albumin-authors' observations).

The concept that the distribution of thiosulfate in the body is predominantly confined to the extracellular spaces depends upon the evidence that the anion is largely excreted by glomerular filtration. Gilman, Philips, and Koelle estab- 
lished in the dog a thiosulfate creatinine clearance ratio of unity (3). Extension of these studies to the human kidney demonstrated that thiosulfate is excreted by the glomerulus, since thiosulfate and inulin clearances were identical (6). It is possible to apply clearance data and calculate a volume of distribution for the material studied by means of the formula $\mathrm{V}=\frac{\mathrm{C}}{\mathrm{S}}$, when $\mathrm{V}$ represents the volume of distribution, $\mathrm{C}$ the clearance and $\mathrm{S}$ the slope of the logarithm of the serum concentration with respect to time (9). The application of this formula to the clearance data of the dog by Gilman, Philips, and Koelle revealed volumes of distribution ranging from $21.3 \%$ to $24.2 \%$ of the body weight (3). Schwartz estimated clearance by means of an infusion technique, and obtained thiosulfate spaces in two humans of 15.7 and $19.5 \%$ body weight respectively (10). These figures for thiosulfate space are in fairly close agreement with inulin space measurements (1).

Ideally a substance used for fluid compartment measurements should not be metabolized or the metabolism should be known and correctable. A portion of injected thiosulfate is metabolized and excreted as sulfate $(11,12)$. The sites of oxidation may be the liver and kidney $(11,13)$. Evidence obtained in the dog with ligated ureters indicates that thiosulfate is slowly destroyed at a rate proportional to its plasma concentration (3). This value averages only $7 \%$ of the renal clearance. Should this logarithmic relationship hold in the human subject, correction for metabolic destruction is possible.

Thiosulfate has a long history of use in clinical medicine, where it has been given extensively by the intravenous route for heavy metal poisoning. The anion is considered non-toxic except for occasional nausea and vomiting $(14,15)$.

\section{CONCLUSIONS}

1. Thiosulfate is not appreciably bound by non-diffusible components of human serum.

2. Thiosulfate penetrates the human erythrocyte.

3. Since it appears to be distributed predominantly in the "extracellular fluid" and is nontoxic, thiosulfate may be useful for estimating the size of the "extracellular fluid" volume.

\section{ACKNOWLEDGMENT}

We wish to acknowledge the assistance and cooperation of Dr. I. Herbert Scheinberg for his help in the planning of this study, and Dr. W. E. Reynolds for his advice and assistance in the interpretation of the data.

\section{REFERENCES}

1. Levitt, M. F., and Gaudino, M., Measurement of body water compartments. Am. J. Med., 1950, 9, 208.

2. Scheinberg, I. H., and Kowalski, H. J., The binding of thiocyanate to albumin in normal human serum and defibrinated blood with reference to the determination of "thiocyanate space." J. Clin. Invest., 1950, 29, 475.

3. Gilman, A., Philips, F. S., and Koelle, E. S., The renal clearance of thiosulfate with observations on its volume distribution. Am. J. Physiol., 1946, 146, 348.

4. Scatchard, G., Scheinberg, I. H., and Armstrong, S. H., Jr., Physical chemistry of protein solutions. IV. The combination of human serum albumin with chloride ion. J. Am. Chem. Soc., 1950, 72, 535.

5. Scatchard, G., Scheinberg, I. H., and Armstrong, S. H., Jr., Physical chemistry of protein solutions. V. The combination of human serum albumin with thiocyanate ion. J. Am. Chem. Soc., 1950, 72, 540.

6. Newman, E. V., Gilman, A., and Philips, F. S., The renal clearance of thiosulfate in man. Bull. Johns Hopkins Hosp., 1946, 79, 229.

7. Hawk, P. B., Oser, B. L., and Summerson, W. H., Practical Physiological Chemistry. The Blakiston Co., Philadelphia, 1947, Ed. 12, p. 422.

8. Gibson, J. G., II, Peacock, W. C., Seligman, A. M., and Sack, T., Circulating red cell volume measured simultaneously by the radioactive iron and dye methods. J. Clin. Invest., 1946, 25, 838.

9. Newman, E. V., Bordley, J., III, and Winternitz, J., The interrelationships of glomerular filtration rate (mannitol clearance), extracellular fluid volume, surface area of the body, and plasma concentration of mannitol. Bull. Johns Hopkins Hosp., 1944, 75, 253.

10. Schwartz, I. L., Measurement of extracellular fluid by means of a constant infusion technique without collection of urine. Am. J. Physiol., 1950, 160, 526.

11. Elaut, L., Excretion of sodium thiosulphate by the perfused kidney. J. Urol., 1931, 26, 241.

12. Franklin, J., Genest, J., and Newman, E., The mechanism of excretion of ammonium thiosulfate. Bull. Johns Hopkins Hosp., 1947, 81, 168.

13. Pirie, N. W., The oxidation of thiosulphate to sulphate by tissue slices in vitro. Biochem. J., 1934, 281, 1063.

14. Litwins, J., Boyd, L. J., and Greenwald, L., The action of sodium thiosulphate on the blood. Exper. Med. \& Surgery, 1943, 1, 252.

15. Goodman, L., and Gilman, A., The Pharmacological Basis of Therapeutics. Macmillan Co., New York, 1941, p. 743. 